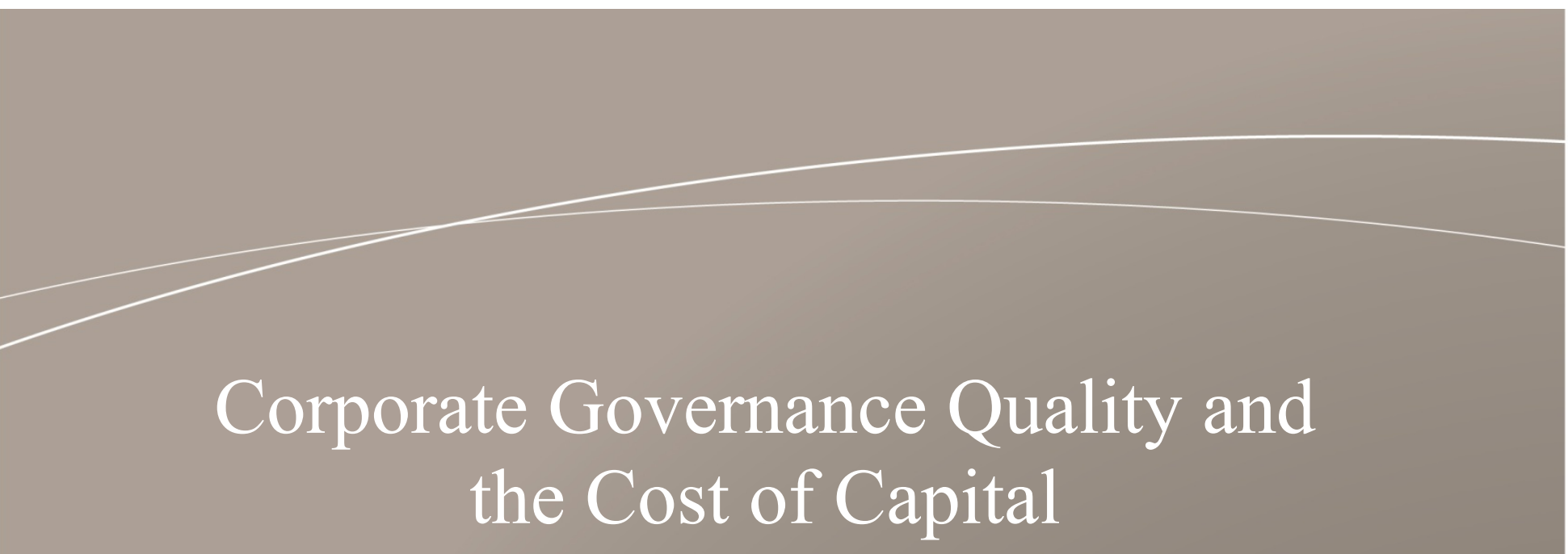

\author{
Yves Bozec \\ Richard Bozec
}
WORKING PAPER
WP.10.06

May 2010

ISSN 0701-3086 


\title{
Corporate Governance Quality and the Cost of Capital
}

\author{
Yves Bozec \\ HEC Montreal \\ 3000 Chemin de la Côte-Sainte-Catherine \\ Montréal (Québec) H3T 2A7, Canada \\ Phone : +1 (514) 340-6560 \\ Fax : +1 (514) 340-5633 \\ yves.bozec@hec.ca \\ Richard Bozec \\ University of Ottawa \\ Telfer School of Management \\ 55 Laurier E \\ Ottawa, Ontario K1N 6N5, Canada \\ Phone: + 1 (613) 562-5800 Ext. 4739 \\ Fax: + 1 (613) 562-5164 \\ bozec@telfer.uottawa.ca
}

May 2010 


\title{
Corporate Governance Quality and the Cost of Capital
}

\begin{abstract}
The objective of this study is to further investigate what channel causes firms with weak (strong) corporate governance to be valued less (more) by investors. Specifically, we examine the relationship between corporate governance scores and firms' cost of capital, including both equity capital and debt. This research is conducted in Canada over a fouryear period from 2002 to 2005 and uses panel data of 155 S\&P/TSX firms. The quality of firm-level governance is measured based on the ROB index published by The Globe and Mail. Using fixed-effect regressions in a 2SLS framework, we find strong evidence that the cost of equity/debt decreases as the quality of corporate governance practices increases. Canadian firms with higher ROB scores have a lower cost of capital.
\end{abstract}

Keywords: Corporate governance, ROB governance indexes, cost of capital, Canada.

JEL classification: G34 


\section{INTRODUCTION}

One important objective of corporate governance is to protect outside investors, including both shareholders and creditors, against expropriation by managers or controlling shareholders (La Porta et al. 2002). In response to recent financial scandals and the subsequent collapse of high profile corporations such as Enron and WorldCom, new market regulations have been launched worldwide and an increasing number of parties including media, institutional investors and shareholders' rights watchdogs are now pushing for higher governance standards. These initiatives are based on a common belief that strong corporate governance is expected to mitigate agency problems by increasing the monitoring of managers, limiting their opportunistic behavior, and thus increasing firm value.

Nowadays, a market has developed for governance services with a growing number of shareholder advisers disclosing indexes that are intended to provide a readily comparable measure of a firm's overall governance quality. A more holistic view of corporate governance has emerged. Scholars now tend to rely on governance ratings rather than firm-specific governance attributes such as ownership structure and board composition. Overall, empirical results of index-based governance studies conducted in Europe and emerging countries show a positive relation between governance scores and firm value and performance. However, studies conducted in the US and Canada have generated mixed evidence (Bozec and Bozec, 2010).

This contrast in the international evidence is puzzling and calls for further investigation. The objective of this study is to address this issue. However, instead of testing the direct link between governance scores and firm value, we analyze the impact 
of governance quality on the cost of capital. We use cost of capital as one channel that may cause firms with weak (strong) corporate governance to be valued less (more) by investors. In that sense, our study proposes an alternative approach to explore the association between corporate governance and firm value.

Studies typically assume that corporate governance affects firm value through its impact on the expected future cash flows. Indeed, corporate governance may affect firm valuation by reducing the level of private benefits extracted by managers or controlling shareholders, thus increasing the expected cash flows that can be distributed to shareholders (cash flow effect). However, corporate governance may also have value implications through its effect on the firms' cost of capital, i.e. the rate the investors apply to discount expected cash flows (cost of capital effect). According to Hail and Leuz (2006), it is possible that the valuation effects of corporate governance reflect the risk premium demanded by investors. In their view, effective corporate governance, in terms of higher firm transparency and better disclosure, reduces information asymmetries and serves to decrease the uncertainty of future cash flows. All else being equal, firms that are less risky should have a lower cost of capital and hence, should be valued more by investors.

The use of cost of capital in index-based governance studies is quite recent. For instance, Chen et al. (2009) provide supporting evidence that better corporate governance practices reduce firms' cost of equity capital in emerging markets. In the same vein, Blom and Schauten (2008) find a negative correlation between governance scores of European firms which make up the FTSE 300 and the cost of debt. 
Our study extends from prior work in the following ways. First, the study is conducted in Canada, a country that offers an interesting setting. Like those in most countries around the world, Canadian firms have controlling shareholders whose voting rights exceed cash flows rights, providing them with both a strong incentive and the power to expropriate minority shareholders (Bozec and Laurin, 2008). However, Canada retains the typical corporate governance and investor protection found in common law countries. These measures are believed to be more effective compared to those in most European and Asian countries (La Porta et al., 1998; Dyck and Zingales, 2004). Therefore, whether, in the Canadian context, the quality of firm-level corporate governance is associated with a decrease in the cost of capital is an open issue.

Second, prior empirical studies relating corporate governance scores and firm value in Canada have shown mixed results (Foerster and Huen, 2004; Klein et al., 2005; Gupta et al., 2009; Bozec et al., 2009). By using cost of capital as a channel through which corporate governance may impact on firm value, this study aims at providing additional means of shedding light on this issue.

Third, prior empirical studies linking corporate governance scores to firms' cost of capital focus on only one aspect of capital, either equity (Chen et al., 2009) or debt (Blom and Schauten, 2008). However, firms most often rely on both sources of capital to finance their investment projects. In order to fully capture the impact of governance quality on the cost of capital, this study uses both cost of equity capital and cost of debt.

To test the governance-cost of capital relationship, we use panel data of 155 Canadian S\&P/TSX firms (517 firm-year observations) covered in the Report on Business (ROB) index published by The Globe and Mail between 2002 and 2005. Results 
show a strong relationship between ROB scores and cost of equity/debt. We interpret this result as evidence that in Canada, better firm governance practices are associated with a decreased cost of capital. We further show that this result is primarily driven by board and disclosure sub-indexes. Our findings are robust to the use of alternative econometrics techniques including fixed-effect panel regressions in a two-stage least squares (2SLS) framework that aim to address any potential problems of endogeneity.

The paper is organized as follows. Section 2 presents prior literature on corporate governance scores, firm value and cost of capital. Section 3 describes the methodology including sample selection, and governance and cost of capital metrics. The results are given in Section 4 and section 5 presents our conclusions.

\section{PRIOR LITERATURE}

\section{Corporate governance quality and firm value}

Corporate governance encompasses the mechanisms that are put in place to assure the shareholders and creditors of the firm of getting a return on their investment (Shleifer and Vishny, 1997). When firms have controlling shareholders, as is the case in most countries around the world (see La Porta et al., 1999; Claessens et al., 2000; Faccio and Lang, 2002), corporate governance mainly deals with agency problems between controlling shareholders and outside investors, including both minority shareholders and creditors. By retaining a large portion of the voting rights, controlling shareholders enjoy almost total control of the firm's operations, providing them with the power to expropriate minority shareholders, as well as creditors (La Porta et al., 2002). What exacerbates the agency problems is that controlling shareholders don't bear the full costs 
of their decisions because often, through the use of dual class shares, pyramidal structures and cross-ownership, they have significant control rights in excess of their cash flow rights (Bebchuk et al., 2000). In such a context, strong corporate governance is intended to protect outside investors against expropriation by the controlling shareholders. The law and finance theory of corporate governance contends that when investors feel adequately protected, they are inclined to participate more actively in the capital market, and are willing to pay more for the firm's securities. In turn, firms enjoy cheaper costs of raising external capital for their investments and also enjoy higher valuation.

Bozec and Bozec (2010) provide a comprehensive review of the international index-based studies investigating the governance-performance relationship. The list of the studies reviewed is reproduced in Table 1. Studies based on US and Canadian markets show conflicting results overall. In contrast, with the exception of Limpaphayom and Connelly (2008) and Price et al. (2010), studies conducted in emerging countries and transitional economies as well as those from Europe have generated results that consistently show a positive relation between corporate governance ratings and firm performance and value.

The following reasons can explain these contrasting results. First, emerging markets are more likely to have poor legal environments, ineffective laws, and weak investor protection, therefore increasing the benefits of establishing effective corporate governance arrangements (La Porta et al., 2002). Second, most emerging markets follow a comply-or-explain approach to governance which allows firms more flexibility in applying governance standards than does a rule-based approach as employed in the US, 
for instance. Studies using samples of emerging countries are therefore more likely to find inter-firm variations in corporate governance practices and thus potentially stronger results.

Corporate governance quality and cost of capital

One channel by which better corporate governance enhances firm value is through its effect on the cost of capital. When shareholders or creditors finance firms, they face a risk that the firm's profit will not come back to them as dividends or interest. Outside investors actually face the risk of being expropriated by controlling shareholders. The higher the risk they face, the higher the risk premium they will demand, and therefore the firm's cost of capital is likely to increase.

Corporate governance arrangements such as better and more timely information disclosure, independent members serving on the board and audit committee, and effective executive compensation, are expected to reduce firms' cost of capital in several ways. First, strong corporate governance serves to better monitor managers' or controlling shareholders' actions and thus contributes to lowering the extraction of private benefits. Meanwhile, by imposing a higher cost for expropriation, corporate governance is also expected to reduce the risk of such expropriation, and hence to reduce the required rate of return (Chen et al., 2009). Second, strong corporate governance, in terms of a higher level of firm transparency and quality of information flow, may serve to decrease information asymmetries between the firm and its outside shareholders or creditors (Verrecchia, 2001). This, in turn, reduces the uncertainty of a firm's future cash flows and facilitates the estimation of risk (Clarkson et al., 1996). Third, as argued by Lombardo and Pagano 
(2002), transparent corporate accounts and better disclosure reduce external monitoring costs borne by outside investors. It follows that when outside investors can monitor managers or controlling shareholders more cheaply and effectively, they will demand a lower required rate of return.

Theoretically, strong corporate governance is therefore expected to lower firms' risk and thus, firms' cost of capital. From the shareholders' point of view, lower firm risk will be reflected on the discount rate they will apply to a firm's expected future cash flows. Hence, firms will enjoy a lower cost of equity capital. As their rights are more tightly specified than those of shareholders, debt holders mainly face a risk of default. When corporate governance reduces default risk, creditors will accept a reduction in their risk premium, which in turn, lowers the firm's cost of debt.

Despite being limited in number, index-based studies provide supporting evidence on the negative link between governance and cost of capital (Blom and Schauten, 2008; Chen et al., 2009).

\section{SAMPLE SELECTION AND DATA}

\section{Sample Selection}

This study covers a period of four years from 2002 to 2005. Canada experienced important reforms during this period including the enactment of Bill 198 in 2002, the equivalent of the Sarbanes Oxley Act in the US. Therefore, we expect more variation in corporate governance practices during this time frame, a precondition for the use of panel regressions. Moreover, the ROB index and the weight assigned to each provision are 
relatively consistent across the four-year period under investigation. Substantial changes have been made in the construction of the index in the following years.

We initially selected firms covered in the 2005 Globe and Mail survey (hereafter, Report on Business or ROB) ${ }^{1}$. This survey is based on 209 firms listed on the S\&P/TSX composite index. In line with previous studies, we deleted financial companies from the sample $(\mathrm{n}=28)$ given their unique characteristics. We also deleted firms with insufficient data to compute the set of variables described below $(n=26)$. Our final sample is an unbalanced panel data of 155 Canadian firms and 517 firm-years observations.

\section{Estimating the Cost of Equity (CE)}

The primary approach suggested by academics and used in the industry to estimate a company's cost of equity is the capital asset pricing model (CAPM) (see Graham and Harvey, 2001; Welch, 2008; Da et al., 2009). CAPM is calculated as follows:

$$
r_{E}=\mathbf{R f}+\boldsymbol{\beta}[\mathbf{E}(\mathbf{R m})-\mathbf{R f}]
$$

The implementation of the CAPM requires a risk-free rate (Rf), the estimation of the sensitivity of the stock returns to changes in market returns - the beta coefficient $(\beta)$ and, the equity premium $(E(R m)-R f)$, which quantifies the expected excess return on the market $(\mathrm{E}(\mathrm{Rm}))$ over the risk-free rate $(\mathrm{Rf})$.

The choice of the appropriate risk-free rate is motivated by the average length of a project of a firm. Because most firms use a long-term government bond yield, such as the yield to maturity on 10-year Treasury bonds as the risk-free rate (Bierman, 1993; Bruner et al., 1998), we assume an average project life of 10 years and use the 10-year 
Government of Canada benchmark yield prevailing at the date of the computation of cost of capital.

In estimating the equity premium $(\mathrm{E}(\mathrm{Rm})-\mathrm{Rf})$, we rely on Booth (2001) who provides statistical evidence for Canadian data over the past four decades that stocks outperformed bonds by about 3\%. However, as this estimate is influenced by a period of high government deficits in the 70s that pushed interest rates upwards and conditions on bond markets have changed since then, Booth recommends using an equity premium of about $4.5 \%$ for the Canadian market.

Having assessed the risk-free rate and the equity risk premium, we then use the previous five years of monthly return data from CRSP (Center for Research in Security Prices) to estimate a firm-year beta coefficient by regressing a firm's returns on the equity risk premium. All returns represent total returns and take into account reinvested dividend payments.

\section{Estimating the After-Tax Cost of Debt (CD)}

We assess a firm's cost of debt from its credit rating. More specifically, based on a firm's credit rating, we add a fraction or multiple of the difference between the weighted-average, long-term senior corporate bond yields computed by Scotia Capital Inc. minus the 10-year Government of Canada benchmark yield (credit spread) to the 10year Government of Canada benchmark yield. ${ }^{2}$ For all firms for which Compustat provides an S\&P long-term senior debt rating, we assign the firm to one of four categories. For firms rated AAA to A-, we add 0.5 times the credit spread. For ratings from $\mathrm{BBB}+$ to $\mathrm{BB}$, we apply the credit spread for the average corporate bond. For ratings 
from BB- to B, we add 1.5 times the credit spread, and for firms with ratings below B, we add twice the credit spread. For all remaining firms without an S\&P rating, we base our cost of debt estimate on Altman's (1968) Z-score. ${ }^{3}$ For healthy firms with a Z-score below 1.81 (financially healthy firms), we use the 10-year Treasury bond rate plus the average corporate credit spread. For firms with a Z-score between 1.81 and 3, we add 1.5 times the credit spread, and for firms with Z-scores above 3 (unhealthy firms), we add two times the credit spread.

We then apply the tax rate of the firm to compute the after-tax cost of debt (CG). The tax rate should represent the marginal tax rate of the firm. The balance sheet provides information about the average tax rates which we use as an approximation of a firm's marginal tax rate. For all firms in our sample, we compute the average ratio over the past three years of income tax payments divided by income before taxes. To avoid excessive estimates resulting as an artefact of accounting regulations on deferred taxes and tax credits, we trim these tax rates at $50 \%$.

Table 2 reports descriptive statistics of cost of equity capital as well as cost of debt for our sample. The average cost of equity for Canadian firms is $8.9 \%$ for the period under investigation (2002-2005). This is somewhat lower than the cross-country average of 12.7\% reported by Hail and Leuz (2006) between 1992 and 2001. Table 2 also shows an average cost of debt of $5.8 \%$.

\section{Corporate Governance Metrics}

Following previous Canadian studies (e.g. Klein et al., 2005; Bozec et al., 2009), we define firm-level governance practices using the index developed by ROB which 
captures a wide variety of governance indicators. Indeed, the ROB index is based on a set of practices identified by regulators and investor groups as critical to corporate governance effectiveness. The ROB index distinguishes between four blocks of corporate governance. The first block, board composition, (maximum of 37 marks out of 100), assesses the independence of the members serving on the board, the audit committee, the compensation committee and the remuneration committee. The second block deals with compensation (maximum of 25 marks) and captures, among other things, whether the directors and the CEO are required to own stocks. The third block, shareholder rights (maximum of 28 marks), evaluates different scenarios that could impair shareholder rights including the presence of nonvoting or subordinate shares, and employee stock options. Finally, the fourth block (Disclosure) measures both the availability and the quality of information on corporate governance (maximum of 10 marks). Appendix A presents the major criteria considered within the ROB rating categories for 2005.

Since our study uses panel data, the index and the weight assigned to each provision must be consistent across the four-year period under investigation. This condition is largely met for the ROB index from 2002 to 2005 . When minor differences do exist, we re-estimated the weights of the indexes and sub-indexes in line with the weighting scales of the ROB index of 2005. For instance, the maximum allocated to the board composition sub-index was 40 marks from 2002 to 2004 but only 37 marks in 2005. In that case, the adjustment consists of multiplying the sub-index "Board Composition" from 2002 to 2004 by 37/40. A similar process was carried out to standardize the other sub-indexes. 
The use of commercial ratings has recently been criticized for not equally weighting governance indicators and, as a result, for being too subjective (Daines et al., 2008). In an attempt to test the reliability and credibility of the ROB index, we collected the 2004 corporate governance ratings for each firm in our sample from Institutional Shareholder Services (ISS), a well established US governance index (CGQ ratings). The ISS index was available for 121 firms from our sample. Pearson correlation tests reveal that the 2004 total ROB index (TOTAL) and ISS global indexes are highly correlated (57\%). Similar results are found using the board sub-index from ROB and ISS (58\%), adding credibility to the ROB index employed in our study.

Table 2 presents descriptive statistics of the ROB governance indexes. The average index (TOTAL) is 68 out of 100. The highest mark is 92 and the lowest 37, indicating a large variation in the index among the sample companies. ROB scores are significantly different across industries (not reported here).

(Take in Table 2)

\section{Control variables}

We collect the following firm-level characteristics from Stock Guide: SIZE, DEBT, and Market-to-Book ratio (MB). ${ }^{4}$ These control variables are presented in Appendix B.

Firm size (SIZE) is defined as the log of total assets. In contrast to small firms, large cap companies are usually more diversified, potentially reducing firm risk and consequently cost of equity capital and cost of debt. This contention is supported 
empirically by Hail and Leuz (2006) and Botosan and Plumlee (2005). Therefore, we expect the cost of capital to be negatively correlated to SIZE.

Leverage (DEBT) measures the level of debt, defined as the book value of longterm debt over total assets. Although leverage (DEBT) offers tax savings because interest payments are tax deductible, higher leverage is also associated with higher risk (risk of bankruptcy) and, hence, higher cost of equity (Fama and French, 1992; Gode and Mohanran, 2003). Therefore, a positive association between DEBT and the cost of equity capital and debt is expected.

Market-to-book ratio (MB) which is used as a proxy for growth opportunities is defined as the market value of equity over the book value. The relation a priori between the cost of capital and growth opportunities (MB) is difficult to predict. On the one hand, high growth firms are expected to be riskier, leading one to anticipate a positive association with the cost of capital. On the other hand, growth opportunities are expected to produce higher future cash flows, higher stock returns and thus a lower cost of capital. Empirical evidence (Hail and Leuz, 2006; Botosan and Plumlee, 2005) suggests a negative relationship between $\mathrm{MB}$ and the cost of capital.

For firms in our sample, Table 2 shows that the average size (SIZE) is 14.55 , the average firm leverage (DEBT) is $31 \%$, and the average market-to-book ratio (MB), is 2.71. Overall, these statistics are broadly consistent with prior Canadian studies (see, for example, Klein et al., 2005) which tend to use similar samples, mainly large cap firms.

\section{Correlation matrix}


Table 3 reports Pearson's correlation coefficients between the key variables for the period under investigation. ${ }^{5}$ Results show a negative correlation between the overall ROB index (TOTAL), each of the four ROB sub-indexes (BOARD, COMPENSATION, SHAREHOLDER, and DISCLOSURE) and both cost of capital (CE) and cost of debt (CD) $(\mathrm{P}<0.01$ across each pair except for SHAREHOLDER). These results provide preliminary support for the expected negative link between firm-level governance scores and the cost of capital. In addition, and as expected, $\mathrm{CE}$ and $\mathrm{CD}$ are negatively correlated with SIZE, suggesting that larger firms tend to be less risky. However, the negative correlation between the cost of capital and DEBT is somewhat unexpected, suggesting that high leveraged firms have lower cost of equity capital. Table 3 also shows that larger firms as well as those with high debt tend to be well-governed as indicated by the positive correlation coefficients between SIZE, DEBT and ROB indexes.

(Take in Table 3)

\section{EMPIRICAL TESTS AND RESULTS}

\section{Panel Regressions}

As our first empirical test, we perform panel regressions using the following model for the sample period 2002-2005:

$\mathrm{CC}_{\mathrm{it}}=\delta+\theta_{1}$ ROB-GOV $_{\mathrm{it}}+\theta_{2}$ SIZE $_{\mathrm{it}}+\theta_{3} \mathrm{DEBT}_{\mathrm{it}}+\theta_{4} \mathrm{MB}_{\mathrm{it}}+\theta_{\mathrm{i}}$ Fixed Effects $+\varepsilon_{1}$

Where the cost of capital (CC), namely the cost of equity capital (CE) and the cost of debt (CD), is regressed against firm-level corporate governance (ROB-GOV) using total ROB index and each of the four ROB sub-indexes. The following firm-specific controls are included in Equation (1): firm size (SIZE), leverage (DEBT), market-to-book 
ratio (MB). In addition, we control for fixed effects of firm (FIRM) and time (YEAR) in order to capture any unobserved firm and/or year heterogeneity that could be driving both ROB and cost of capital. Since good corporate governance practices are expected to decrease agency risk, and hence lower the firm's cost of capital, ROB scores should be negatively correlated with $\mathrm{CE}$ and $\mathrm{CD}$.

Table 4 reports the results of estimating Equation (1) using the cost of equity (CE) as the dependent variable. In model 1 , the coefficient for TOTAL, the ROB overall governance score, is negative and statistically significant at the $1 \%$ level. In models 2 to 5 , using each of the four ROB sub-indexes individually, we show a negative relationship between ROB sub-indexes and $\mathrm{CE}$, except for the shareholder sub-index (SHAREHOLDER). The results appear to be stronger, both in statistical and economical terms, for the board sub-index (BOARD) and the disclosure sub-index (DISCLOSURE). These results are also consistent with those reported from model 6 which includes all four ROB sub-indexes.

Overall, the results from Table 4 suggest that the cost of equity capital decreases as corporate governance practices improve. This is particularly true when Canadian firms put in place more effective boards and disclose better information. The negative relationship found between the disclosure sub-index (DISCLOSURE) and cost of equity capital is consistent with the cross-country evidence in Hail and Leuz (2006).

As for the control variables, the results show that the cost of equity capital decreases with firm size and growth but increases with leverage. However, the coefficients for DEBT and MB are, in general, not significant at conventional levels.

(Take in Table 4) 
Table 5 reports the results for the cost of debt (CD) as the dependent variable. A strong negative association is found between TOTAL and CD $(\mathrm{P}<0.01)$. As shown in model 6 , these results appear to be driven by the board sub-index (BOARD) and the disclosure sub-index (DISCLOSURE). Overall, we interpret these results as evidence that better-governed Canadian firms enjoy a lower cost of debt. These results are consistent with those of Blom and Schauten (2008) and suggest that debt holders take a firm's corporate governance into account when estimating its default risk, therefore reducing the risk premium demanded for well-governed firms.

Table 5 also shows that larger firms (more leveraged firms) have lower (higher) cost of debt, as expected. In addition, a positive relation is found between $\mathrm{CD}$ and $\mathrm{MB}$, suggesting that ceteris paribus, high growth firms are perceived as more risky by debt holders.

(Take in Table 5)

\section{SLS Panel Regressions}

The risk of endogeneity arises when a missing variable from the regression model is determining both the explanatory variable (ROB in our case) and the dependent variable (cost of capital), leading to a spurious correlation The fixed-effect methodology used in our study helps to alleviate that risk. In particular, we use firm fixed effects to capture unobserved time-invariant firm level factors, and year dummies to control variation over time that is common to all firms.

However, endogeneity may also involve reverse causality. In our case, it means that corporate governance (ROB) may cause cost of capital which in turn may cause 
ROB. Black and Kim (2008) and Black et al. (2009) provide compelling evidence of the endogeneous nature of corporate governance. To reduce that risk, we run instrumental variables in a two-stage least squares (2SLS) panel regressions framework. The challenge with this approach is to find good instruments, that is, variables that are correlated with the endogenous variable (ROB), but uncorrelated (or not directly correlated) with the dependent variables (CE and $\mathrm{CD}$ ). Given the lack of a specific theoretical framework, we follow previous Canadian studies using the ROB index (Klein et al., 2005; Bozec and Bozec, 2007) and consider, as a potential instrument, a dummy variable indicating whether or not the firm is cross-listed on a US stock exchange (US-Listed). Recent studies (e.g. Doidge, 2004; Ben-Amar and André, 2006) consider cross-listing in the US as a signal that the foreign firm accepts tighter regulation including increased governance scrutiny, which may result in better governance ratings.

About $40 \%$ of our sampled firms are listed on a US exchange. Consistent with Klein et al. (2005), we find US-Listed to be highly correlated with the ROB index and sub-indexes but uncorrelated with the cost of capital (CE and CD), a preliminary indication of the instrument's validity. ${ }^{6}$ Using US-Listed as an instrument for ROB, we run the following system of equations:

$$
\begin{aligned}
\text { ROB }_{\text {it }}= & \alpha+\beta_{1} \text { US-Listed }_{\text {it }}+\beta_{2} \text { SIZE }_{\mathrm{it}}+\beta_{3} \text { DEBT }_{\mathrm{it}}+\beta_{4} \mathrm{MB}_{\mathrm{it}} \\
& +\beta_{\mathrm{j}} \text { Fixed Effects }_{\mathrm{j}}+\varepsilon_{1} \\
\mathrm{CC}_{\mathrm{it}}= & \delta+\theta_{1} \text { Instrumented ROB }_{\mathrm{it}}+\theta_{2} \text { SIZE }_{\mathrm{it}}+\theta_{3} \mathrm{DEBT}_{\mathrm{it}} \\
& +\theta_{4} \mathrm{MB}_{\mathrm{it}}+\theta_{\mathrm{i}} \text { Fixed Effects }+\varepsilon_{2}
\end{aligned}
$$


In the first stage (Equation 2a), ROB index is regressed on the instruments, including US-Listed, to obtain the fitted values. Equation (2b) is the second-stage regression that uses the fitted values from the first stage to define an instrumental variable for ROB (Instrumented $\mathrm{ROB}_{\mathrm{it}}$ ). In doing so, we estimate the association between ROB indexes and cost of capital while taking into consideration the endogenous nature of the ROB indexes.

2SLS panel regression results on cost of equity are reported in Table 6, and those on cost of debt, in Table 7. Regression (2a) of Table 6 is the first stage. It shows that US cross-listing (US-Listed) is a strong predictor of corporate governance ratings. As expected, the coefficient of US-Listed is positive and statistically significant $(\mathrm{P}<0.01)$. Canadian firms cross-listed in the US tend to adopt better corporate governance practices than do those that are not. We also note that the explanatory power of the model is high (Adjusted $\mathrm{R}^{2}$ : $33 \% ; \mathrm{P}<0.01$ ). Therefore, these results support the use of US-Listed as a valid instrument for the ROB indexes.

(Take in Table 6)

Models 1 to 5 report results from the second-stage regressions. Model 1 uses the instrumented ROB TOTAL variable and models 2 to 5 , the instrumented ROB subindexes. ${ }^{7}$ The coefficients for TOTAL, BOARD, COMPENSATION and DISCLOSURE are still negative and statistically significant at conventional levels supporting a robust and strong relationship between a firm's governance practices and the cost of equity capital (CE). Accordingly, the 2SLS results of Table 6 are consistent with the one obtained from panel regressions (Table 4). 
The 2SLS results of Table 7 are also consistent with those presented in Table 5. In any case, the cost of debt is found to be strongly negatively associated with corporate governance (TOTAL index as well as sub-indexes, except SHAREHOLDER).

(Take in Table 7)

\section{Additional robustness checks}

To further test the robustness of our results, we conducted the following additional tests. First, the Hausman (1978) test to compare the fixed and random effects estimates of coefficients marginally rejects the null hypothesis of equal coefficients $(\mathrm{P}<0.07)$. Therefore, we re-run our 2SLS panel regressions presented in Tables 6 and 7 using firm random effects instead of firm fixed effects. In unreported regressions, we obtain qualitatively similar results.

Second, we consider other potential instruments for ROB scores including family ownership and deviation from the one share--one vote principle. Firms controlled by a family are common in Canada, even among the largest publicly listed firms (Bozec and Laurin, 2008; King and Santor, 2007). Family firms are characterized by a high level of ownership concentration and a frequent deviation from the one share--one vote rule, leading to a family's voting rights well exceeding its cash-flow rights. In a related study, Bozec and Bozec (2007) find a strong negative association between ownership concentration, excess voting rights, and ROB scores. We thus follow Bozec and Bozec (2007) and use as potential instruments the following: FAMILY, a dummy variable indicating whether or not the firm is controlled by a family and WEDGE, the excess voting rights. Although not reported here, when these two instruments are used instead of 
the US cross-listing variable, a negative association remains between ROB indexes and both CE and CD.

Third, our measure of the after-tax cost of debt (CD) uses firms' accounting tax rate instead of the marginal tax rate since the latter is not available. The average accounting tax rate for firms in our sample is about $23 \%$. We suspect marginal tax rate to be lower than accounting rate. As an alternative, we re-estimate $\mathrm{CD}$ before tax. Results still show that high ROB reduces firms' risks and hence, the cost of debt.

\section{CONCLUSION}

Overall, index-based studies investigating the governance-performance relationship have generated mixed evidence (Bozec and Bozec, 2010). In this paper, we explore one possible channel that causes firms with effective corporate governance to be valued more by investors: the cost of capital. We argue that effective corporate governance, in terms of higher firm transparency and better disclosure, is expected to reduce information asymmetries and the uncertainty of future cash flows. Therefore, firms that are less risky should have lower cost of capital and hence, higher valuation.

This research is conducted in Canada over a four-year period from 2002 to 2005 and uses panel data of $155 \mathrm{~S} \& \mathrm{P} / \mathrm{TSX}$ firms. The quality of firm-level governance is measured based on the ROB index published by The Globe and Mail. We study both components of the cost of capital: the cost of equity capital and the cost of debt. We find strong evidence that the cost of capital is decreasing with the quality of corporate governance. Indeed, Canadian firms with higher ROB scores have a lower cost of equity 
capital and cost debt. This result appears to be driven by the board and disclosure subindexes.

Our paper contributes to the literature in several ways. First, the findings of Hail and Leuz (2006) suggest that firms in countries with more extensive disclosure requirements have a significantly lower cost of equity capital. Our study extends Hail and Leuz's findings by using a much broader firm-level corporate governance index. In addition to the disclosure index, ROB covers the effectiveness of the board of directors, compensation policies, and shareholder rights.

Second, Chen et al. (2009) investigate the link between corporate governance and cost of equity in emerging markets. While Canada resembles emerging markets in terms of ownership concentration, yet the legal protection of investors is believed to be much stronger. Therefore, our study of the Canadian context complements the literature by showing that cost of equity is still a decreasing function of strong corporate governance.

Third, while previous index-based studies focus on either the cost of equity capital (Chen et al., 2009) or cost of debt (Blom and Schauten, 2008), our study provides evidence on cost of capital including both cost of equity and cost of debt. This is important because firms usually rely on multiple sources of financing. Our results suggest that outside investors, including shareholders as well as debt holders, impose a lower risk premium for firms with effective corporate governance.

Fourth, our paper contributes to the policy debate as to whether or not we should impose stringent governance regulations on firms. Our results give support to post-Enron reforms that push for more homogeneity in corporate governance practices. It follows that 
firms with stronger corporate governance have access to cheaper sources of capital. This in turn may contribute to the growth of firms as well as economies.

However, our findings are subject to limitations, the most important one being related to the measurement of cost of capital. As argued by Hail and Leuz (2006), the cost of capital is difficult to measure. In this study, we estimate the cost of equity based on realized stock returns (CAPM). This approach is generally seen as less powerful compared to those estimating the ex ante cost of capital implied in share prices and analysts' forecasts. Our choice of CAPM is dictated by the availability of data. However, to alleviate these concerns, we use both cost of equity and cost of debt. Our results are consistent under both metrics which is a positive indication of the validity of our measures. 


\section{REFERENCES}

Aggarwal, R. and R. Williamson. 2006. "Did New Regulations Target the Relevant Corporate Governance Attributes?" Working Paper available on the Social Science Research Network, Electronic Library at: www.ssrn.com.

Altman, Edward I. 1968. "Financial Ratios, Discriminant Analysis and the Prediction of Corporate Bankruptcy." Journal of Finance, p. 189-209.

Bai, C., Q. Liu, J. Lu, F.M. Song and J. Zhang. 2004. "Corporate Governance and Market Valuation in China." Journal of Comparative Economics, Vol. 32 (4), p. 599-616.

Balasubramanian, N., S.B. Black and V. Khanna. 2008. "Firm-Level Corporate Governance in Emerging Markets: A Case Study of India." Working Paper available on the Social Science Research Network, Electronic Library at: www.ssrn.com.

Bauer, R., N. Gunster and R. Otten. 2004. "Empirical Evidence on Corporate Governance in Europe." Journal of Asset Management, Vol.5, p. 91-104.

Bauer, R., B. Frijns, R. Otten and A. Tourani-Rad. 2008. "The Impact of Corporate Governance on Corporate Performance: Evidence from Japan." Pacific-Basin Finance Journal, Vol. 16, p. 236-251.

Bebchuk, L., Kraakman, R., and Triantis. G. 2000. "Stock Pyramids, Cross-Ownership, and Dual Class Equity: The Creation and Agency Cost of Separating Control from Cash Flow Rights.” In Randall K. Morck (Ed.), Concentrated Corporate Ownership Chicago, IL: University of Chicago Press, p. 295-315.

Bebchuck, L.A., A. Cohen and A. Ferrell. 2009. "What Matters in Corporate

Governance?" Review of Financial Studies, Vol. 22 (2), p. 783-827.

Beiner, S., W. Drobetz, M.M. Schmid and H. Zimmermann. 2006. "An Integrated Framework of Corporate Governance and Firm Valuation." European Financial Management, Vol. 12 (2), p. 249-283.

Ben-Amar, W. and P. André. 2006. "Separation of Ownership and Control and Acquisition Firm Performance: The Case of Family Ownership in Canada." Journal of Business, Finance \& Accounting, Vol. 33(3), p. 517-43.

Bhagat, S. and B. Bolton. 2008. "Corporate Governance and Firm Performance." Journal of Corporate Finance, Vol. 14, p. 257-273.

Bierman, Harold Jr. 1993. "Capital Budgeting in 1992: A Survey." Financial Management, Fall 1992, p. 24. 
Black, Bernard S. and Woochan Kim (2008). "The Effect of Board Structure on Firm Value: A Multiple Identification Strategies Approach Using Korean Data." Working Paper, at http://ssrn.com/abstract=968287.

Black, S.B. 2001. "The Corporate Governance Behavior and Market Value of Russian Firms.” Emerging Markets Review, Vol. 2, p. 89-108.

Black, S.B., H. Jang and W. Kim. 2006a. "Does Corporate Governance Predict Firm's Market Values? Evidence from Korea." Journal of Law, Economics \& Organization, Vol. 22 (2), p.366-413.

Black, S.B., I. Love and A. Rachinsky. 2006b. "Corporate Governance Indices and Firms' Market Values: Time Series Evidence from Russia.. Emerging Markets Review, Vol. 7, p. 361-379

Black, S.B., W. Kim, H. Jang and K-S Park. 2009. "How Corporate Governance Affects Firm Value: Evidence on Channels from Korea." Working Paper available on the Social Science Research Network, Electronic Library at: www.ssrn.com.

Blom, J. and M.B.J. Schauten. 2008. "Corporate Governance and the Cost of Debt." In: Soares, J.O., Pina, J. and M. Catalao-Lopes, New Developments in Financial Modeling, Cambridge Scholars Publishing, p. 116-145.

Booth, Lawrence. 2001. "Equity Market Risk Premiums in the U.S. and Canada." Canadian Investment Review, Fall 2001, 34-43.

Botosan, C. and M. Plumlee. 2005. "Assessing Alternative Proxies for Expected Risk Premium." The Accounting Review, Vol. 80, p. 21-53.

Bozec, R. and Y. Bozec. 2010. "The Use of Corporate Governance Indexes in the Governance-Performance Literature: International Evidence.” Working Paper, University of Ottawa.

Bozec, R., M. Dia and Y. Bozec. 2009. "Governance-Performance Relationship: A Reexamination Using Technical Efficiency Measures." British Journal of Management, Published online.

Bozec, Y. and R. Bozec. 2007. "Ownership Concentration and Corporate Governance Practices: Substitution or Expropriation Effect?" Canadian Journal of Administrative Sciences, Vol. 24(3), p.182-195.

Bozec, Y. and C. Laurin. 2008. "Large Shareholder Entrenchment and Performance: Empirical Evidence from Canada." Journal of Business Finance and Accounting, Vol. 35(1), p. 25-49. 
Brown, L.D. and M.L. Caylor. 2004. "Corporate Governance and Firm Performance." Working Paper available on the Social Science Research Network, Electronic Library at: www.ssrn.com.

Brown, L.D. and M.L. Caylor. 2005. "Corporate Governance and Firm Operating Performance." Working Paper available on the Social Science Research Network, Electronic Library at: www.ssrn.com.

Brown, L.D. and M.L. Caylor. 2006. "Corporate Governance and Firm Valuation." Journal of Accounting and Public Policy, Vol. 25, p. 409-434.

Bruner, Robert F., Kenneth M. Eades, Robert S. Harris, and Robert C.Higgins. 1998. "Best Practices in Estimating the Cost of Capital: Survey and Synthesis." Financial Practice and Education, Spring/Summer 1998, p. 13-28.

Chen, K.C.W., Z. Chen and K.C.J. Wei. 2009. "Legal Protection of Investors, Corporate Governance, and the Cost of Equity Capital." Journal of Corporate Finance, Vol. 15, p. 273-289.

Cheng, D. and Y.Y. Wu. 2006. "Evolving Corporate Governance and Equity Prices: The Recent Evidence." Working Paper available on the Social Science Research Network, Electronic Library at: www.ssrn.com.

Cheng, C.S.A., D. Collins and H. Huang. 2006. "Investors' Interpretations of the October 15, 2002 Standard \& Poors Transparency \& Disclosure Rankings." Working Paper available on the Social Science Research Network, Electronic Library at: www.ssrn.com.

Cheung, Y.L, J.T. Connelly, P. Limpaphayom and L. Zhou. 2007. "Do Investors Really Value Corporate Governance? Evidence from the Hong Kong Market." Journal of International Financial Management and Accounting, Vol. 18 (2), p. 86-122.

Chidambaran, N.K., D.Palia and Y. Zheng. 2008. "Corporate Governance and Firm Performance: Evidence from Large Governance Changes." Working Paper available on the Social Science Research Network, Electronic Library at: www.ssrn.com.

Clacher, I., E. Doriye and D. Hillier. 2008. "Does Corporate Governance Matter? New Evidence from the United Kingdom." Working Paper available on the Social Science Research Network, Electronic Library at: www.ssrn.com.

Claessens, S., S. Djankov and L. Lang. 2000. "The Separation of Ownership and Control in East Asia Corporations." Journal of Financial Economics, Vol. 58, p. 81-112.

Clarkson, P., J. Guedes and R. Thompson. 1996. "On The Diversification, Observability, and Measurement of Estimation Risk." Journal of Financial and Quantitative Analysis, Vol. 31 p. 69-84. 
Core, J.E., W. Guay and T. Rusticus. 2006. "Does Weak Governance Cause Weak Stock Returns? An Examination of Firm Operating Performance and Investors' Expectations." Journal of Finance, Vol. 61 (2), p. 655-687.

Daines, R., I. Gow and D. Larker. 2008. "Rating the Ratings: How Good are Commercial Governance Ratings?" Working Paper available on the Social Science Research Network, Electronic Library at: www.ssrn.com.

Da, Zhi, Re-Jin Guo, and Ravi Jagannathan. 2009. "CAPM for Estimating the Cost of Equity Capital; Interpreting the Empirical Evidence." Working Paper available on the Social Science Research Network, Electronic Library at: www.ssrn.com.

Doidge, C. 2004. "US Cross-Listings and the Private Benefits of Control: Evidence from Dual Class Firms.” Journal of Financial Economics, Vol.72, p. 519-53.

Drobetz, W., A. Schillhofer and H. Zimmermann. 2004. "Corporate Governance and Expected Stock Returns: Evidence from Germany." European Financial Management, Vol. 10 (2), p. 267-293.

Durnev, A and E.H. Kim. 2005. "To Steal or Not to Steal: Firm Attributes, Legal Environment, and Valuation.” Journal of Finance, Vol.60 (3), p. 1461-1493.

Dyck, A., and L. Zingales. (2004). "Private Benefits of Control: An International Comparison." Journal of Finance, Vol. 59(2), p. 537-600.

Epps, R.W. and S.J. Cereola. 2008. "Do Institutional Shareholder Services (ISS) Corporate Governance Ratings Reflect a Company's Operating Performance?" Critical Perspectives in Accounting, Vol. 19, p. 1135-1148.

Faccio, M. and L. Lang, 2002. "The Ultimate Ownership of Western European Corporations.” Journal of Financial Economics, Vol. 65, p. 365-395.

Fama, E. and K. French. 1992. "The Cross-Sections of Expected Stock Returns." Journal of Finance, Vol.47, p. 427-468.

Fernandez-Rodriguez, E., S. Gomez-Anson and A. Cuervo-Garcia. 2004. "The Stock Market Reaction to the Introduction of Best Practices Codes by Spanish Firms." Corporate Governance: An International Review, Vol. 12 (1), p. 29-46.

Fodor, A. and D. Diavatopoulos. 2010. "Does Corporate Governance Matter For Equity Returns?" Working Paper available on the Social Science Research Network, Electronic Library at: www.ssrn.com.

Foerster, S. R. and B. C. Huen. 2004. "Does Corporate Governance Matter to Canadian Investors?” Canadian Investment Review, Vol.17 (3), p. 19-23. 
Garay, U. and M. Gonzalez. 2008. "Corporate Governance and Firm Value: The Case of Venezuela." Corporate Governance: An International Review, Vol. 16 (3), p. 194-209.

Gode, D. and P. Mohanram, 2003, "Inferring the Cost of Capital Using the OhlsonJuettner Model.” Review of Accounting Studies, Vol. 8, p. 399-431.

Gompers, P., J. Ishii and A. Metrick. 2003. "Corporate Governance and Equity Prices." The Quarterly Journal of Economics, Vol. 118, p. 107-155.

Graham, John R., and Campbell R. Harvey. 2001. "The Theory and Practice of Corporate Finance: Evidence from the Field." Journal of Financial Economics, Vol. 60, p. 187-243.

Gupta, P. P., D. B. Kennedy and S. W. Weaver. 2009. "Corporate Governance and Firm Value: Evidence from Canadian Capital Markets." Corporate Ownership and Control, Vol. 6 (3), p. 293-307.

Hail, L. and C. Leuz. 2006. "International Differences in the Cost of Equity Capital: Do Legal Institutions and Securities Regulation Matter?" Journal of Accounting Research, Vol. 44 (3), p. 485-531.

Hausman, J. A. 1978. "Specification Tests in Econometrics." Econometrica, Vol. 46, p. 1251-1271.

Johnson, S.A., T. Moorman and S. Sorescu. 2008. "A Reexamination of Corporate Governance and Equity Prices." Working Paper available on the Social Science Research Network, Electronic Library at: www.ssrn.com.

King M. R. and E. Santor. 2007. "Family Values: Ownership Structure, Performance and Capital Structure of Canadian Firms." Working Papers 07-40, Bank of Canada.

Klapper, L.F. and I. Love. 2004. "Corporate Governance, Investor Protection and Performance in Emerging Markets." Journal of Corporate Finance, Vol. 10 (5), p. 703 728.

Klein, P., D. Shapiro and J. Young. 2005. "Corporate Governance, Family Ownership and Firm Value: The Canadian Evidence." Corporate Governance: An International Review, Vol.13 (6), p. 769-784.

Koehn, D. and J. Veng. 2005. "Evaluating the Evaluators: Should Investors Trust Corporate Governance Metrics Ratings?" Journal of Management and Governance, Vol. 9, p. 111-128.

La Porta, R., F. Lopez-de-Silanes and A. Shleifer. 1999. "Corporate Ownership Around the World." Journal of Finance, Vol. 54, (2), p. 471-518. 
La Porta, R., F. Lopez-de-Silanes, A. Shleifer, and R. W. Vishny. 2002. "Investor Protection and Corporate Valuation." Journal of Finance, Vol. 57, p. 1147-1170.

La Porta, R., F. Lopez-de-Silanes, A. Shleifer, and R. Vishny, 1998, Law and Finance, Journal of Political Economy, Vol. 106, p. 1113-1155.

Lehn, K., S. Patro and M. Zhao. 2007. "Governance Indices and Valuation: Which Causes Which?” Journal of Corporate Finance, Vol. 13, p. 907-928.

Limpaphayom, P. and J.T. Connelly. 2008. "Corporate Governance in Thailand." Working Paper available on the Social Science Research Network, Electronic Library at: www.ssrn.com.

Lombardo, D. and M. Pagano.2002. "Law and Equity Markets: A Simple Model.” In Joseph A.McCahery, ed.: Corporate Governance Regimes: Convergence and Diversity (Oxford University Press, London).

Mohanty, P. 2003. "Institutional Investors and Corporate Governance in India." Working Paper available on the Social Science Research Network, Electronic Library at: www.ssrn.com.

Pagett, C. and A. Shabbir. 2005. "The UK Code of Corporate Governance: Link between Compliance and Firm Performance." Working Paper available on the Social Science Research Network, Electronic Library at: www.ssrn.com.

Price, R., F. Roman and B. Rountree. 2010. "The Impact of Governance Reform on Performance and Transparency." Journal of Financial Economics, Forthcoming.

Renders, A., A. Gaeremynck and P. Sercu. 2010. "Corporate Governance Ratings and Company Performance: A Cross European Study." Corporate Governance: An International Review, Vol. 18 (2), p. 87-106.

Shleifer, A. and R. Vishny, 1997, "A Survey of Corporate Governance." Journal of Finance, Vol. 52, p. 737-783.

Spellman, G.K. and R. Watson. 2009. "GMI Ratings and Corporate Performance: 2003 to 2008." Working Paper available on the Social Science Research Network, Electronic Library at: www.ssrn.com.

Toledo, E.P. 2009. "The Relationship Between Corporate Governance and Firm Value: A Simultaneous Equations Approach for Analyzing the Case of Spain." Working Paper available on the Social Science Research Network, Electronic Library at: www.ssrn.com.

Toudas, K. and G. Karathanassis. 2007. "Corporate Governance and Firm Performance: Results from Greek Firms." Working Paper available on the Social Science Research Network, Electronic Library at: www.ssrn.com. 
Verrecchia, R. 2001. "Essays on Disclosure.” Journal of Accounting \& Economics, Vol. 32 , p. $91-180$.

Welch, Ivo. 2008. "The Consensus Estimate for the Equity Premium by Academic Financial Economists in December 2007.” Working paper, Brown University.

White, H. 1980. "A Heteroskedasticity-Consistent Covariance Matrix Estimator and a Direct Test for Heteroskedasticity." Econometrica, Vol. 48, p. 817-838.

Zheka, V. 2006. "Does Corporate Governance Causally Predict Firm Performance? Panel Data and Instrumental Variables Evidence." Working Paper available on the Social Science Research Network, Electronic Library at: www.ssrn.com. 


\section{Appendix A \\ Major criteria considered within the Report on Business (ROB) corporate governance rating categories for 2005}

The overall ROB index comprises four categories or sub-indexes which in turn include different factors. The data were obtained from the proxy information circular for shareholders. The maximum weight assigned to each factor is shown in brackets.

\section{1- Board composition (37 marks)}

-Independence of the board of directors, the audit committee, the compensation committee and the nominating committee (19 marks)

-Duality structure (position held by the Chairman and the CEO) (5 marks)

-Relationship between directors (3 marks)

-Engagement of the CEO versus other outside commitments (2 marks)

-Women on the board (2 marks)

-Performance evaluation of the board (3 marks)

-Meetings of the board without management (3 marks)

2- Compensation (25 marks)

-Stocks owned by directors and CEO (13 marks)

-Loans to senior executives (2 marks)

-Disclosure of compensation policies regarding CEO bonuses (4 marks)

-Disclosure of compensation policies regarding CEO and top executives (6 marks)

3- Shareholder rights (28 marks)

-Election of the board (6 marks)

-Degree of dilution when stock options are owned by employees (6 marks)

-Other option plans (6 marks)

-Presence of non-voting or subordinate voting shares (10 marks)

4- Disclosure (10 marks)

-Related directors (1 mark)

-Directors' biography (1 mark)

-Disclosure of fees paid to an outside compensation consultant (1 mark)

-Attendance record of directors at committees and meetings ( 2 marks)

-Disclosure of the compensation paid to directors last year (3 marks)

-Disclosure of directors' ages and retirement policies (2 marks) 


\section{Appendix B}

\section{Variables definition}

\begin{tabular}{|c|c|}
\hline $\begin{array}{l}\text { Cost of capital } \\
\text { Cost of equity }(C E) \\
\text { Cost of debt }(C D)\end{array}$ & $\begin{array}{l}\text { Risk-free rate }+(\text { Beta } \times \text { Equity premium }) \\
\text { Multiple of the difference between the average, weighted, long-term corporate bond yields } \\
\text { minus the } 10 \text {-year Government of Canada benchmark yield (credit spread) to the } 10 \text {-year } \\
\text { Government of Canada benchmark yield. }\end{array}$ \\
\hline $\begin{array}{l}\quad \text { Governance Index } \\
\text { TOTAL } \\
\text { BOARD } \\
\text { COMPENSATION } \\
\text { SHAREHOLDER } \\
\text { DISCLOSURE }\end{array}$ & $\begin{array}{l}\text { ROB total index } \\
\text { ROB sub-index related to the board structure and composition. } \\
\text { ROB sub-index related to the directors' and CEO's stock ownership. } \\
\text { ROB sub-index related to employees' stock options and the presence of nonvoting shares. } \\
\text { ROB sub-index related to the quality and availability of information on corporate governance. }\end{array}$ \\
\hline $\begin{array}{l}\quad \text { Instrument: } \\
\text { US-Listed } \\
\quad \text { Control Variables: } \\
\text { SIZE } \\
D E B T \\
M B \\
Y E A R\end{array}$ & $\begin{array}{l}1 \text { if the firm is cross-listed on a US stock exchange, otherwise } 0 \\
\text { Logarithm of total assets at the end of the financial year } \\
\text { Long-term debt over total assets at the end of the financial year } \\
\text { Market value of equity over book value at the end of the financial year } \\
\text { Dummies for 2002, 2003, 2004, and } 2005 \text { ( } 2005 \text { is the reference year) }\end{array}$ \\
\hline
\end{tabular}


Table 1

Empirical Studies Using Governance Indexes Classified by Results (taken from Bozec and Bozec, 2010)

\begin{tabular}{|c|c|}
\hline Positive relation & No relation found \\
\hline \multicolumn{2}{|c|}{ Emerging Countries and Transitional Economies } \\
\hline $\begin{array}{ll}\text { - } & \text { Black (2001) } \\
\text { - } & \text { Mohanty (2003) } \\
\text { - } & \text { Kai et al. (2004) } \\
\text { - } & \text { Durner and Love (2004) } \\
\text { - } & \text { Black et al. (2006a) } \\
\text { - } & \text { Black et al. (2006b) } \\
\text { - } & \text { Zheka (2006) } \\
\text { - } & \text { Cheung et al. (2007) } \\
\text { - } & \text { Bauer et al. (2008) } \\
\text { - } & \text { Balasubramanian et al. (2008) } \\
\text { - } & \text { Garay and Gonzalez (2008) } \\
\text { - } & \text { Black et al. }(2009) \\
& \text { Chen et al. (2009) }\end{array}$ & $\begin{array}{ll} & \text { Limpaphayom and Connelly (2008) } \\
\text { - } & \text { Price et al. (2010) }\end{array}$ \\
\hline \multicolumn{2}{|c|}{ Europe } \\
\hline $\begin{array}{ll}\text { - } & \text { Fernandez-Rodriguez et al. (2004) } \\
\text { - } & \text { Drobetz et al. (2004) } \\
\text { - } & \text { Bauer et al. (2004) } \\
\text { - } & \text { Pagett and Shabbir (2005) } \\
\text { - } & \text { Beiner et al. (2006) } \\
\text { - } & \text { Toudas and Karathanassis (2007) } \\
\text { - } & \text { Clacher et al. (2008) } \\
\text { - } & \text { Blom and Schauten (2008) } \\
\text { - } & \text { Renders et al. (2010) } \\
\text { - } & \text { Toledo (2009) } \\
\end{array}$ & \\
\hline \multicolumn{2}{|c|}{ United States (US) } \\
\hline $\begin{array}{ll}\text { - } & \text { Gompers et al. (2003) } \\
\text { - } & \text { Brown and Caylor (2004) } \\
\text { - } & \text { Brown and Caylor (2005) } \\
\text { - } & \text { Cheng et al. (2006) } \\
\text { - } & \text { Aggarwal and Williamson (2006) } \\
\text { - } & \text { Cheng and Wu (2006) } \\
\text { - } & \text { Spellman and Watson (2009) } \\
\text { - } & \text { Bebchuk et al. (2009) }\end{array}$ & $\begin{array}{ll} & \text { Koehn and Veng (2005) } \\
\text { - } & \text { Core et al. (2006) } \\
\text { - } & \text { Lehn et al. (2007) } \\
\text { - } & \text { Bhagat and Bolton (2008)* } \\
\text { - } & \text { Chidambaran et al. (2008) } \\
\text { - } & \text { Johnson et al. (2008) } \\
\text { - } & \text { Daines et al. (2008) } \\
\text { - } & \text { Epps and Cereola (2008) } \\
\text { - } & \text { Fodor and Diavatopoulos (2010) }\end{array}$ \\
\hline \multicolumn{2}{|c|}{ Canada } \\
\hline $\begin{array}{ll}\text { - } & \text { Foerster and Huen (2004) } \\
\text { - } & \text { Bozec et al. (2009) }\end{array}$ & $\begin{array}{ll} & \text { Klein et al. (2005)* } \\
\text { - } & \text { Gupta et al. (2009) }\end{array}$ \\
\hline
\end{tabular}

* Mixed results 


\section{Table 2}

\section{Descriptive Statistics}

This table reports summary statistics on cost of capital, ROB index, and other firm characteristics for a sample of 155 firms or 517 firm/year observations, between 2002 and 2005. See Appendix $\mathrm{B}$ for definitions of variables.

N Mean Min $\quad$ Max $\begin{gathered}\text { Standard } \\ \text { dev. }\end{gathered}$

\section{Cost of capital :}

Cost of equity (CE)

Cost of debt (CD)

$\begin{array}{lllll}517 & 0.087 & 0.036 & 0.205 & 0.028 \\ 517 & 0.058 & 0.046 & 0.075 & 0.006\end{array}$

\section{ROB index :}

TOTAL

$\begin{array}{ccccc}517 & 68 & 35 & 92 & 14 \\ 517 & 28 & 6 & 37 & 8 \\ 517 & 12 & 1 & 19 & 4 \\ 517 & 20 & 4 & 28 & 6 \\ 517 & 9 & 2 & 10 & 3\end{array}$

Firm-Level control variables :

SIZE

$\begin{array}{lllll}517 & 14.55 & 10.45 & 17.54 & 1.40\end{array}$

DEBT

$\begin{array}{lllll}517 & 0.31 & 0.00 & 0.91 & 0.21\end{array}$

Market-to-Book (MB)

$\begin{array}{llll}517 & 2.71 & 0.23 & 9.40\end{array}$


Table 3

Pearson Correlation Matrix

This table presents a Pearson correlation matrix of the dependent and independent variables. See Appendix B for definitions of the variables.

$*$ and $* *$ indicate statistical significance at $5 \%$ and $1 \%$ levels, respectively.

\begin{tabular}{|c|c|c|c|c|c|c|c|c|c|c|}
\hline & $\mathbf{C E}$ & CD & TOTAL & BOARD & $\begin{array}{l}\text { COMPEN- } \\
\text { SATION } \\
\end{array}$ & $\begin{array}{c}\text { SHARE- } \\
\text { HOLDER } \\
\end{array}$ & DISCLOSURE & SIZE & DEBT & MB \\
\hline Cost of equity (CE) & 1.000 & $0.352^{* *}$ & $-0.314^{* *}$ & $-0.193^{* *}$ & $-0.253^{* *}$ & $-0.214^{* *}$ & $-0.232^{* *}$ & $-0.275^{* *}$ & $-0.236^{* *}$ & $-0.099^{*}$ \\
\hline Cost of debt (CD) & & 1.000 & $-0.282^{* *}$ & $-0.186^{* *}$ & $-0.235^{* *}$ & -0.009 & $-0.484^{* *}$ & $-0.246^{* *}$ & 0.040 & $0.193^{* *}$ \\
\hline TOTAL & & & 1.000 & $0.827^{* *}$ & $0.663^{* *}$ & $0.563^{* *}$ & $0.616^{* *}$ & $0.392^{* *}$ & $0.219^{* *}$ & -0.057 \\
\hline BOARD & & & & 1.000 & $0.389^{* *}$ & $0.183^{* *}$ & $0.447^{* *}$ & $0.207^{* *}$ & $0.149^{* *}$ & -0.024 \\
\hline COMPENSATION & & & & & 1.000 & $0.194^{* *}$ & $0.448^{* *}$ & $0.506^{* *}$ & $0.345^{* *}$ & $-0.094^{*}$ \\
\hline $\begin{array}{l}\text { SHAREHOLDER } \\
\text { DISCLOSURE }\end{array}$ & & & & & & 1.000 & $\begin{array}{l}0.041 \\
1.000\end{array}$ & $\begin{array}{l}0.211^{* *} \\
0.252^{* *}\end{array}$ & $\begin{array}{l}0.056 \\
0.098^{*}\end{array}$ & $\begin{array}{l}0.024 \\
0.120^{* *}\end{array}$ \\
\hline SIZE & & & & & & & & 1.000 & $0.562^{* *}$ & $-0.278^{* *}$ \\
\hline DEBT & & & & & & & & & 1.000 & $0.097^{*}$ \\
\hline MB & & & & & & & & & & 1.000 \\
\hline
\end{tabular}


Table 4

Results from Panel Regressions of Cost of Equity on ROB Governance Indexes

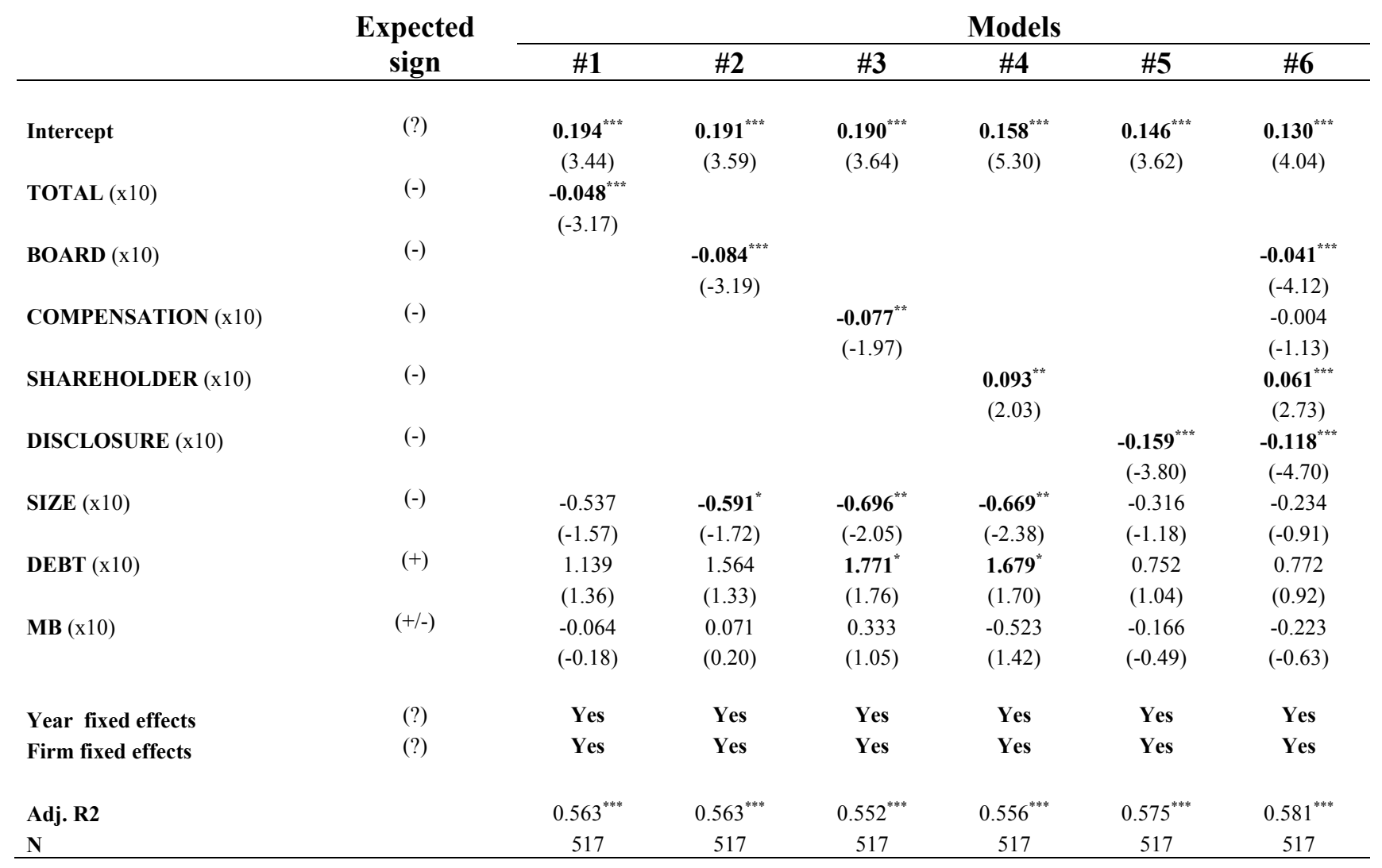

This table reports results from panel regressions of the cost of equity capital on ROB governance indexes. The sample consists of an unbalanced panel data of 155 firms or 517 firm-year observations for the period 2002-2005. The independent variables are the ROB index and sub-indexes (TOTAL, BOARD, COMPENSATION, SHAREHOLDER, and DISCLOSURE). Control variables include SIZE, DEBT, MB, Firm and Year fixed effects. See Appendix B for variable definition. The $t$-value shown under the coefficient is corrected for heteroskedasticity (White, 1980). *, **, $* * *$ indicate statistical significance at $10 \%, 5 \%$, and $1 \%$ levels, respectively. 
Table 5

Results from Panel Regressions of Cost of Debt on ROB Governance Indexes

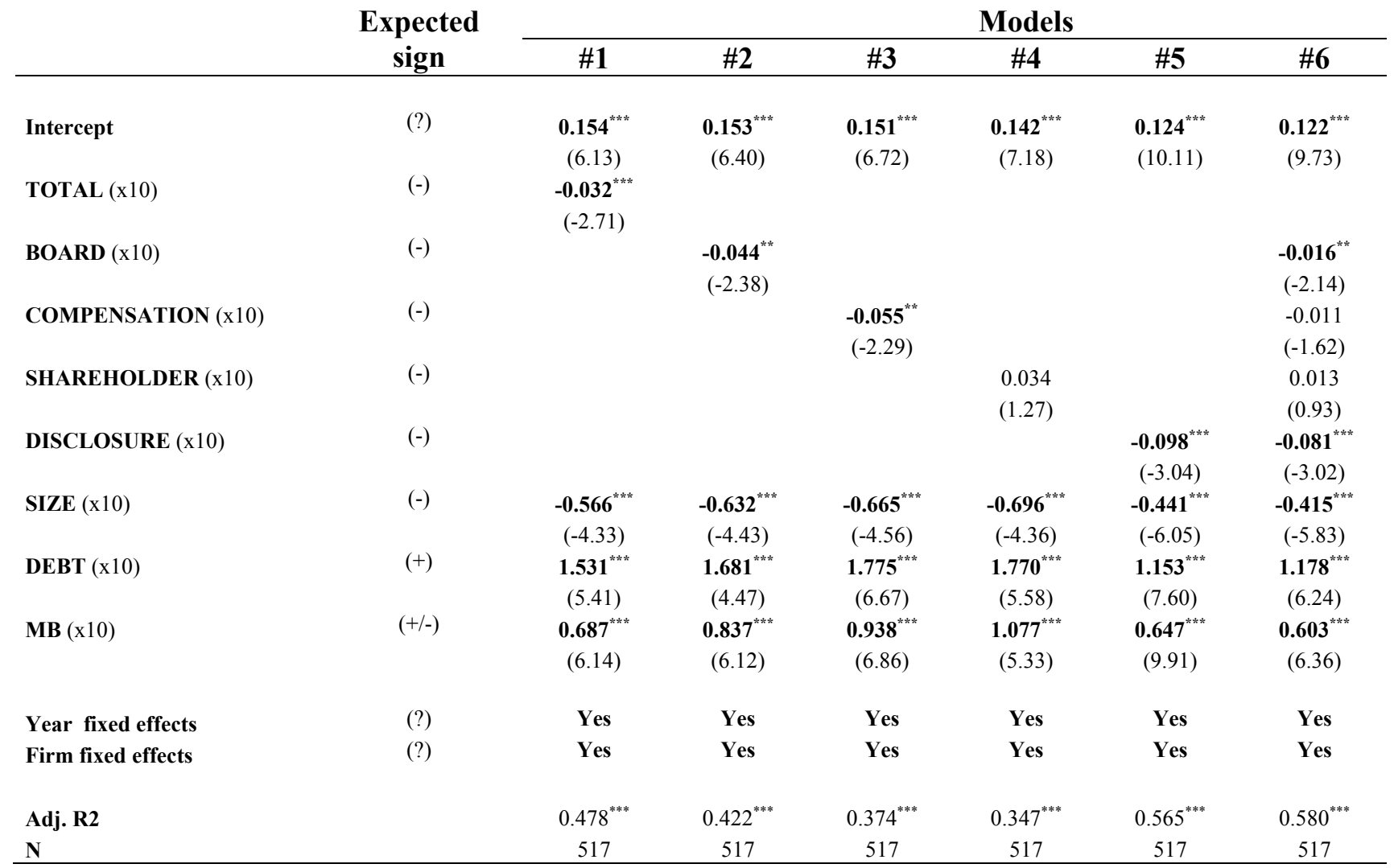

This table reports results from panel regressions of the cost of debt on ROB governance indexes. The sample consists of an unbalanced panel data of 155 firms or 517 firm-year observations for the period 2002-2005. The independent variables are the ROB index and sub-indexes (TOTAL, BOARD, COMPENSATION, SHAREHOLDER, and DISCLOSURE). Control variables include SIZE, DEBT, MB, Firm and Year fixed effects. See Appendix B for variable definition. The $t$-value shown under the coefficient is corrected for heteroskedasticity (White, 1980). *, **, $* * *$ indicate statistical significance at $10 \%, 5 \%$, and $1 \%$ levels, respectively. 
Table 6

Results from 2SLS Panel Regressions of Cost of Equity on ROB Governance Indexes

\begin{tabular}{|c|c|c|c|c|c|c|c|}
\hline & $\begin{array}{c}\text { Expected } \\
\text { sign }\end{array}$ & $\begin{array}{c}\text { TOTAL } \\
(2 \mathbf{a})\end{array}$ & $\# 1$ & $\# 2$ & $\# \mathbf{3}$ & $\# 4$ & $\# 5$ \\
\hline Intercept & (?) & $\begin{array}{c}21.399 \\
(1.29)\end{array}$ & $\begin{array}{c}\mathbf{0 . 1 8 1}^{* * * *} \\
(3.28)\end{array}$ & $\begin{array}{c}\mathbf{0 . 1 7 1} \\
(2.80)\end{array}$ & $\begin{array}{c}\mathbf{0 . 1 2 8}^{* *} \\
(2.26)\end{array}$ & $\begin{array}{l}-0.840 \\
(-1.15)\end{array}$ & $\begin{array}{l}\mathbf{0 . 0 8 8}^{*} \\
(1.99)\end{array}$ \\
\hline US-Listed & $(+)$ & $\begin{array}{c}\mathbf{5 . 9 8 2}^{* * * *} \\
(3.30)\end{array}$ & & & & & \\
\hline TOTAL $(\mathrm{x} 10)$ & $(-)$ & & $\begin{array}{c}-\mathbf{0 . 1 8 3} \\
(-4.89)\end{array}$ & & & & \\
\hline BOARD (x10) & $(-)$ & & & $\begin{array}{c}-\mathbf{0 . 2 8 0} \\
(-3.16)\end{array}$ & & & \\
\hline COMPENSATION (x10) & $(-)$ & & & & $\begin{array}{l}\mathbf{- 0 . 8 3 6} \\
(-15.86)\end{array}$ & & \\
\hline SHAREHOLDER (x10) & $(-)$ & & & & & $\begin{array}{c}\mathbf{0 . 5 3 2}^{* * * *} \\
(8.03)\end{array}$ & \\
\hline DISCLOSURE (x10) & $(-)$ & & & & & & $\begin{array}{c}-\mathbf{- 0 . 3 4 4}^{* * * *} \\
(-8.56)\end{array}$ \\
\hline SIZE $(x 10)^{b}$ & $(-)$ & $\begin{array}{c}\mathbf{2 . 6 4 0}^{* * *} \\
(2.38)\end{array}$ & $\begin{array}{l}0.074 \\
(0.21)\end{array}$ & $\begin{array}{l}0.025 \\
(0.89)\end{array}$ & $\begin{array}{l}0.437 \\
(1.01)\end{array}$ & $\begin{array}{l}0.459 \\
(1.03)\end{array}$ & $\begin{array}{l}0.253 \\
(0.84)\end{array}$ \\
\hline DEBT $(x 10)^{\mathrm{b}}$ & $(+)$ & $\begin{array}{l}3.649 \\
(1.08)\end{array}$ & $\begin{array}{l}0.336 \\
(0.52)\end{array}$ & $\begin{array}{l}-0.817 \\
(-0.66)\end{array}$ & $\begin{array}{l}0.974 \\
(0.92)\end{array}$ & $\begin{array}{l}0.196 \\
(0.12)\end{array}$ & $\begin{array}{l}-0.522 \\
(-1.16)\end{array}$ \\
\hline $\mathbf{M B}(\mathrm{x} 10)^{\mathrm{b}}$ & $(+/-)$ & $\begin{array}{c}-\mathbf{3 . 4 2 2}^{\text {****}} \\
(-2.68)\end{array}$ & $\begin{array}{c}-1.628^{\text {**** }} \\
(-5.21)\end{array}$ & $\begin{array}{c}-1.047^{* * *} \\
(-3.22)\end{array}$ & $\begin{array}{c}-1.622^{* * * *} \\
(-7.21)\end{array}$ & $\begin{array}{l}0.176 \\
(0.74)\end{array}$ & $\begin{array}{c}-\mathbf{0 . 9 7 6} 6^{* * * *} \\
(-3.43)\end{array}$ \\
\hline $\begin{array}{l}\text { Year fixed effects } \\
\text { Firm fixed effects }\end{array}$ & $\begin{array}{l}? \\
?\end{array}$ & $\begin{array}{l}\text { Yes } \\
\text { Yes }\end{array}$ & $\begin{array}{l}\text { Yes } \\
\text { Yes }\end{array}$ & $\begin{array}{l}\text { Yes } \\
\text { Yes }\end{array}$ & $\begin{array}{l}\text { Yes } \\
\text { Yes }\end{array}$ & $\begin{array}{l}\text { Yes } \\
\text { Yes }\end{array}$ & $\begin{array}{l}\text { Yes } \\
\text { Yes }\end{array}$ \\
\hline Adj. $\mathbf{R} 2$ & & $0.329^{* * * *}$ & $0.538^{* * * *}$ & $0.572^{* * *}$ & $0.382^{* * * *}$ & $0.659^{* * *}$ & $0.537^{* * *}$ \\
\hline $\mathbf{N}$ & & 517 & 517 & 517 & 517 & 517 & 517 \\
\hline
\end{tabular}

This table reports results from 2SLS panel regressions of the cost equity capital on ROB governance indexes. The sample consists of an unbalanced panel data of 155 firms or 517 firm-year observations for the period 2002-2005. US-Listed is used to instrument ROB governance indexes. The independent variables are the ROB instrumented indexes (TOTAL, BOARD, COMPENSATION, SHAREHOLDER, and DISCLOSURE). Control variables include SIZE, DEBT, MB, firm and year fixed effects. See Appendix $\mathrm{B}$ for variable definition. The t-value shown under the coefficient is corrected for heteroskedasticity (White, 1980). ${ }^{*}, * *, * *$ indicate statistical significance at $10 \%, 5 \%$, and $1 \%$ levels, respectively. 
Table 7

Results from 2SLS Panel Regressions of Cost of Debt on ROB Governance Indexes

\begin{tabular}{|c|c|c|c|c|c|c|}
\hline & Expected sign & & & & & \\
\hline & & $\# 1$ & \#2 & \#3 & $\# 4$ & $\# 5$ \\
\hline Intercept & (?) & $\begin{array}{c}\mathbf{0 . 1 2 9}^{\text {***** }} \\
(4.20)\end{array}$ & $\begin{array}{c}\mathbf{0 . 1 1 3}^{\text {***** }} \\
(4.95)\end{array}$ & $\begin{array}{c}\mathbf{0 . 0 9 4}^{* * * *} \\
(4.71)\end{array}$ & $\begin{array}{l}0.005 \\
(0.02)\end{array}$ & $\begin{array}{c}\mathbf{0 . 0 7 7}^{* * * *} \\
(5.86)\end{array}$ \\
\hline US-Listed & $(+)$ & & & & & \\
\hline TOTAL $(\mathrm{x} 10)$ & $(-)$ & $\begin{array}{c}-\mathbf{- 0 . 0 7 8}^{* * * *} \\
(-3.62)\end{array}$ & & & & \\
\hline BOARD $(x 10)$ & $(-)$ & & $\begin{array}{c}\mathbf{- 0 . 1 1 6}^{* *} \\
(-2.44)\end{array}$ & & & \\
\hline COMPENSATION (x10) & $(-)$ & & & $\begin{array}{c}\mathbf{- 0 . 3 7 8}^{* * * *} \\
(-18.19)\end{array}$ & & \\
\hline SHAREHOLDER (x10) & $(-)$ & & & & $\begin{array}{c}\mathbf{0 . 2 3 7} 7^{* * *} \\
(7.46)\end{array}$ & \\
\hline DISCLOSURE (x10) & $(-)$ & & & & & $\begin{array}{c}-\mathbf{- 0 . 1 5 0}^{* * * *} \\
(-6.23)\end{array}$ \\
\hline SIZE $(x 10)^{b}$ & $(-)$ & $\begin{array}{l}-0.133 \\
(-1.20)\end{array}$ & $\begin{array}{c}\mathbf{- 0 . 1 7 9}^{* *} \\
(-2.06)\end{array}$ & $\begin{array}{l}0.042 \\
(0.27)\end{array}$ & $\begin{array}{l}0.047 \\
(0.27)\end{array}$ & $\begin{array}{l}-0.051 \\
(-0.61)\end{array}$ \\
\hline DEBT $(x 10)^{b}$ & $(+)$ & $\begin{array}{c}\mathbf{0 . 8 4 2}^{\text {****** }} \\
(4.17)\end{array}$ & $\begin{array}{l}\mathbf{1 . 0 5 0}^{* * *} \\
(2.29)\end{array}$ & $\begin{array}{l}\mathbf{1 . 1 1 1}^{* * *} \\
(2.25)\end{array}$ & $\begin{array}{l}0.763 \\
(1.11)\end{array}$ & $\begin{array}{c}\mathbf{0 . 4 6 0}^{* * * * *} \\
(4.77)\end{array}$ \\
\hline $\mathbf{M B}(\mathrm{x} 10)^{\mathrm{b}}$ & $(+/-)$ & $\begin{array}{l}-0.077 \\
(-0.50)\end{array}$ & $\begin{array}{c}\mathbf{0 . 2 5 2} \\
(-3.02)\end{array}$ & $\begin{array}{l}-0.055 \\
(-0.63)\end{array}$ & $\begin{array}{c}\mathbf{0 . 7 6 0}^{* * * *} \\
(3.77)\end{array}$ & $\begin{array}{c}\mathbf{0 . 2 5 7} \\
(-5.24)\end{array}$ \\
\hline Year fixed effects & $?$ & Yes & Yes & Yes & Yes & Yes \\
\hline Firm fixed effects & $?$ & Yes & Yes & Yes & Yes & Yes \\
\hline Adj. R2 & & $0.187^{* * *}$ & $0.265^{* * *}$ & $0.179^{* * *}$ & $0.259^{* * *}$ & $0.396^{* * *}$ \\
\hline $\mathbf{N}$ & & 517 & 517 & 517 & 517 & 517 \\
\hline
\end{tabular}

This table reports results from 2SLS panel regressions of the cost of debt on ROB governance indexes. The sample consists of an unbalanced panel data of 155 firms or 517 firm-year observations for the period 2002-2005. US-Listed is used to instrument ROB governance indexes. The independent variables are the ROB instrumented indexes (TOTAL, BOARD, COMPENSATION, SHAREHOLDER, and DISCLOSURE). Control variables include SIZE, DEBT, MB, firm and year fixed effects. See Appendix B for variable definition. The $t$-value shown under the coefficient is corrected for heteroskedasticity (White, 1980). *, **, *** indicate statistical significance at $10 \%, 5 \%$, and $1 \%$ levels, respectively. 


\section{Endnotes}

${ }^{1}$ The Globe and Mail is one of the most prestigious Canadian newspapers.

${ }^{2}$ We use the weighted-average of senior long-term debt issued by all Canadian firms, in each year under investigation. The yield of Canadian Treasury bonds is taken at the beginning of the years 2002-2005.

${ }^{3}$ The Altman $\mathrm{Z}$ score is one of the first measures professional bond traders use to evaluate a corporate bond. It is used to predict corporate defaults. Altman's (1968) model is specified as follows: $Z=1.2$ (working capital/total assets) +1.4 (retained earnings/total assets) +3.3 (EBIT/total assets) +0.6 (market value of equity/book value of total liabilities) + (sales/total assets).

4 As an alternative proxy for growth opportunities, we also use CAPEX, defined as total capital expenditures (including R\&D expenditures) over total assets. Qualitatively similar results are found.

${ }^{5}$ Similar results are obtained when Pearson's correlations are performed on a yearly basis.

${ }^{6}$ We find that Pearson's correlation coefficients between US-Listed and ROB index and sub-indexes range from $16 \%$ to $22 \%$ for each pair and are statistically significant at $1 \%$. On the contrary, the correlation coefficients between US-Listed and CE (CD) are about 7\% (3\%) and are not statistically different from zero.

${ }^{7}$ In the interests of brevity, we do not report results from the first-stage regressions involving each of the four ROB sub-indexes. These results are consistent with those from regression (2a). US-Listed remains a strong predictor of ROB governance scores. 